\title{
Replacement of Sand with Stone Crushed Powder in Conventional Concrete
}

\author{
*B.Basavaraj ${ }^{1}$, Ravichandra Honnalli ${ }^{2}$, Sagar N S ${ }^{3}$, Praveen Ashok M ${ }^{4}$, \\ Shwetha K C \\ ${ }_{1,2,3,4,5}$ (Department of civil engineering, BITM. Bellary,India) \\ *Corresponding author: *B.Basavaraj
}

\begin{abstract}
Since ancient period, river sand has been used in the construction industry as a dominant material from the level of foundation to the end of a project.Today demand for sand continues to increase to meet the needs of growth in population. Excessive instream sand mining causes the degradation of rivers and creating ecological imbalance. Instream mining lowers the stream bottom, which may lead to bank erosion and may lead for river meandering. It is the need of the hour to investigate for a suitable alternative material for sand like stone crusher powder and granite fines etc. which are available abundantly from crusher units and granite industries. Use of stone crusher powder proves to be economical and eco-friendly which generally considered as unused. The investigations indicate that stone crusher powder has the similar characteristics and performances as that of river sand. In this paper an attempt has been made to investigate the replacement of sand with Stone crusher powder. Strength behavior of concrete with the use of stone crusher powder as a replacement of fine aggregates in different proportions is discussed. Test results are also discussed pertaining to strength and values are compared with conventional concrete.
\end{abstract}

Keywords: Degradation of rivers, Environmental impacts, Stone crusher powder, Alternative material.

\section{Introduction}

Concrete is the most widely used composite material today. The constituents of concrete are coarse aggregate, fine aggregate, binding material and water. Rapid increase in construction activities leads to acute shortage of conventional construction materials. It is conventional that sand is being used as fine aggregate in concrete. For the past two years, the escalation in cost of sand due to administrative restrictions in India, demands comparatively greater cost at around two to three times the cost for crusher waste even in places where river sand is available nearby.The function of the fine aggregate is to assist in producing workability and uniformity in the mixture. The river deposits are the most common source of fine aggregate. Now-a-days the natural river sand has become scarce and very costly. Hence we are forced to think of alternative materials. The Quarry dust may be used in the place of river sand fully or partly. A comparatively good strength is expected when sand is replaced partially or fully with or without concrete admixtures. It is proposed to study the possibility of replacing sand with locally available crusher waste without sacrificing the strength and workability of concrete.

\section{Concrete materials and their properties}

Coarse aggregate of $20 \mathrm{~mm}$ maximum size is used in Reinforced cement concrete work of all types of structures. This is obtained by crushing the stone boulders of size 100 to $150 \mathrm{~mm}$ in the stone crushers. Then it is sieved and the particles passing through $20 \mathrm{~mm}$ and retained on $10 \mathrm{~mm}$ sieve known as course aggregate. The particles passing through $4.75 \mathrm{~mm}$ sieve are called as quarry dust. The quarry dust is used to sprinkle over the newly laid bituminous road as filler between the bitumen and coarse aggregate and manufacturing of hollow blocks. Various physical properties of the concrete materials are tabulated in Table 1.

Table 1: Properties of the materials.

\begin{tabular}{|c|l|}
\hline Material & \multicolumn{1}{|c|}{ Properties } \\
\hline & Maximum size $: 20 \mathrm{~mm}$ \\
& Specific gravity $: 2.98$ \\
& Fineness modulus $: 6.36$ \\
& Density $: 1.58 \mathrm{gm} / \mathrm{cc}$ \\
\hline \multirow{3}{*}{ River sand } & Specific gravity $: 2.53$ \\
& Fineness modulus $: 3.08$ \\
& Density $: 1.63 \mathrm{gm} / \mathrm{cc}$ \\
& Void ratio $: 0.55$ \\
\hline \multirow{2}{*}{ Quarry dust } & Specific gravity $: 2.57$ \\
& Fineness modulus $: 2.41$ \\
& Density $: 1.85 \mathrm{gm} / \mathrm{cc}$ \\
\hline
\end{tabular}




\begin{tabular}{|c|c|}
\hline & Void ratio : 0.42 \\
\hline Ordinary Portland cement & $\begin{array}{l}\text { Specific gravity : } 3.05 \\
\text { Initial setting time : } 30 \mathrm{~min} \text {. } \\
\text { Final setting time : } 220 \mathrm{~min} \\
\text { Fineness : } 8 \% \text { residue } \\
\text { on IS } 90 \\
\text { micron sieve }\end{array}$ \\
\hline Water & $\begin{array}{l}\mathrm{PH}: 7 \\
\text { Density : } 1 \mathrm{gm} / \mathrm{cc}\end{array}$ \\
\hline
\end{tabular}

\subsection{Mix proportioning}

\section{Experimental investigation}

Two grades of concrete M20 and M25 having nominal mix proportion of 1:1.5:3 and 1:1:2 respectively were used by weight and w/c ratio was fixed according to the slump requirement of $60 \mathrm{~mm}$. For this concrete mix, quarry dust was added for replacement of sand from $0 \%$ to $100 \%$ in step of $10 \%$.

\subsection{Casting of specimen}

Mould of size $150 \times 150 \times 150 \mathrm{~mm}$ was used to cast specimens for compression test. Aggregate of size less than $20 \mathrm{~mm}$ and greater than $12.5 \mathrm{~mm}$ were used. The specimens were cast, tested at the age of 7 and 28 days after curing.

\subsection{Fresh concrete workability}

\section{Testing procedure}

To determine consistency of concrete, Slump test was conducted with varying water content and a particular water cement ratio (w/c) which gives the slump of $60 \mathrm{~mm}$ was selected from graph. The various w/c for different proportions of sand and quarry dust was presented in Table 2.

Table 2: Workability of concrete (Slump 60mm)

\begin{tabular}{|c|c|c|}
\hline Fine aggregate & \multicolumn{2}{|c|}{ Water Cement ratio ( w/c ) } \\
\hline Sand: Quarry dust & M20 & M25 \\
\hline $100: 0$ & 0.420 & 0.382 \\
\hline $90: 10$ & 0.435 & 0.387 \\
\hline $80: 20$ & 0.450 & 0.392 \\
\hline $70: 30$ & 0.460 & 0.397 \\
\hline $60: 40$ & 0.480 & 0.400 \\
\hline $50: 50$ & 0.490 & 0.404 \\
\hline $40: 60$ & 0.500 & 0.408 \\
\hline $30: 70$ & 0.510 & 0.412 \\
\hline $20: 80$ & 0.525 & 0.415 \\
\hline $10: 90$ & 0.530 & 0.419 \\
\hline $0: 100$ & 0.540 & 0.425 \\
\hline
\end{tabular}

\subsection{Compression test}

The cube specimens were tested for compressive strength at the end of 7 days and 28 days. The specimens were tested after surface of the specimen dried. The load was applied on the smooth sides without shock and increased continuously until the failure of the specimen. The maximum load withstand by the specimens is noted, mean compressive strength is determined and presented in Table 3.

Table 3: Mean Compressive strength of concrete (in MPa) Fine aggregate

\begin{tabular}{|c|c|c|c|c|}
\hline \multirow{2}{*}{$\begin{array}{c}\text { Sand: } \\
\text { Quarry dust }\end{array}$} & \multicolumn{2}{|c|}{ M20 } & \multicolumn{2}{c|}{ M25 } \\
\cline { 2 - 5 } & $\mathbf{7}$ days & $\mathbf{2 8}$ days & $\mathbf{7}$ days & 28 days \\
\hline $100: 0$ & 19.25 & 22.22 & 23.21 & 31.03 \\
\hline $90: 10$ & 19.67 & 22.67 & 23.54 & 31.19 \\
\hline $80: 20$ & 20.35 & 24.00 & 23.97 & 31.52 \\
\hline $70: 30$ & 20.89 & 25.33 & 24.12 & 31.75 \\
\hline $60: 40$ & 21.33 & 25.77 & 24.29 & 32.54 \\
\hline $50: 50$ & 22.67 & 27.56 & 24.59 & 32.92 \\
\hline $40: 60$ & 20.44 & 26.22 & 23.60 & 31.33 \\
\hline $30: 70$ & 19.25 & 23.56 & 23.37 & 30.87 \\
\hline $20: 80$ & 18.15 & 22.22 & 20.58 & 30.24 \\
\hline $10: 90$ & 17.70 & 20.89 & 20.35 & 29.33 \\
\hline $0: 100$ & 15.85 & 20.44 & 19.67 & 28.33 \\
\hline
\end{tabular}




\subsection{Temperature effect on concrete}

Due to increase in temperature the strength of concrete was affected. To find the loss in strength the concrete cubes were kept at $100^{\circ} \mathrm{C}$ at an age of 28 days for $24 \mathrm{hrs}$ in an oven and then tested in CTM. The strength obtained is presented in Table 4.

Table 4: Mean Compressive strength of concrete at $100^{\circ} \mathrm{C}$

\begin{tabular}{|c|c|c|}
\hline \multirow{2}{*}{ Fine aggregate } & \multicolumn{2}{|c|}{ 28 days } \\
\hline Compressive strength ( in MPa) \\
\hline Sand: Quarry dust & M20 & M25 \\
\hline $100: 0$ & 17.63 & 24.37 \\
\hline $90: 10$ & 18.29 & 24.50 \\
\hline $80: 20$ & 18.52 & 25.15 \\
\hline $70: 30$ & 18.59 & 25.39 \\
\hline $60: 40$ & 19.11 & 25.41 \\
\hline $50: 50$ & 20.74 & 26.75 \\
\hline $40: 60$ & 19.85 & 26.30 \\
\hline $30: 70$ & 19.48 & 25.15 \\
\hline $20: 80$ & 19.33 & 23.87 \\
\hline $10: 90$ & 17.77 & 22.77 \\
\hline $0: 100$ & 16.96 & 19.90 \\
\hline
\end{tabular}

Due to sudden cooling (thermo shock) the strength of concrete was affected. To find the loss in strength the concrete cubes were kept at $100^{\circ} \mathrm{C}$ at an age of 28 days for $24 \mathrm{hrs}$ in an oven and then immersed in water for few minutes and then tested in CTM. The strength obtained is presented in Table 5.

Table 5: Mean Compressive strength of concrete due to thermo shock

\begin{tabular}{|c|c|c|}
\hline Fine aggregate & \multicolumn{2}{|c|}{$\begin{array}{c}\text { 28 days } \\
\text { Compressive strength ( in MPa) }\end{array}$} \\
\hline Sand: Quarry dust & M20 & M25 \\
\hline $100: 0$ & 16.96 & 22.22 \\
\hline $90: 10$ & 17.50 & 22.67 \\
\hline $80: 20$ & 17.63 & 23.56 \\
\hline $70: 30$ & 17.77 & 24.00 \\
\hline $60: 40$ & 18.29 & 24.37 \\
\hline $50: 50$ & 19.33 & 26.00 \\
\hline $40: 60$ & 18.60 & 25.33 \\
\hline $30: 70$ & 18.52 & 24.00 \\
\hline $20: 80$ & 18.29 & 22.22 \\
\hline $10: 90$ & 17.50 & 21.33 \\
\hline $0: 100$ & 16.00 & 18.29 \\
\hline
\end{tabular}

\section{Analysis of test results}

\subsection{Compressive strength}

From the Table 3, it is observed that both the 7 days and 28 days compressive strength is increased for the $50 \%$ replacement of sand at considerable level. The variation in compressive strength is represented in Fig 1 and 2 .

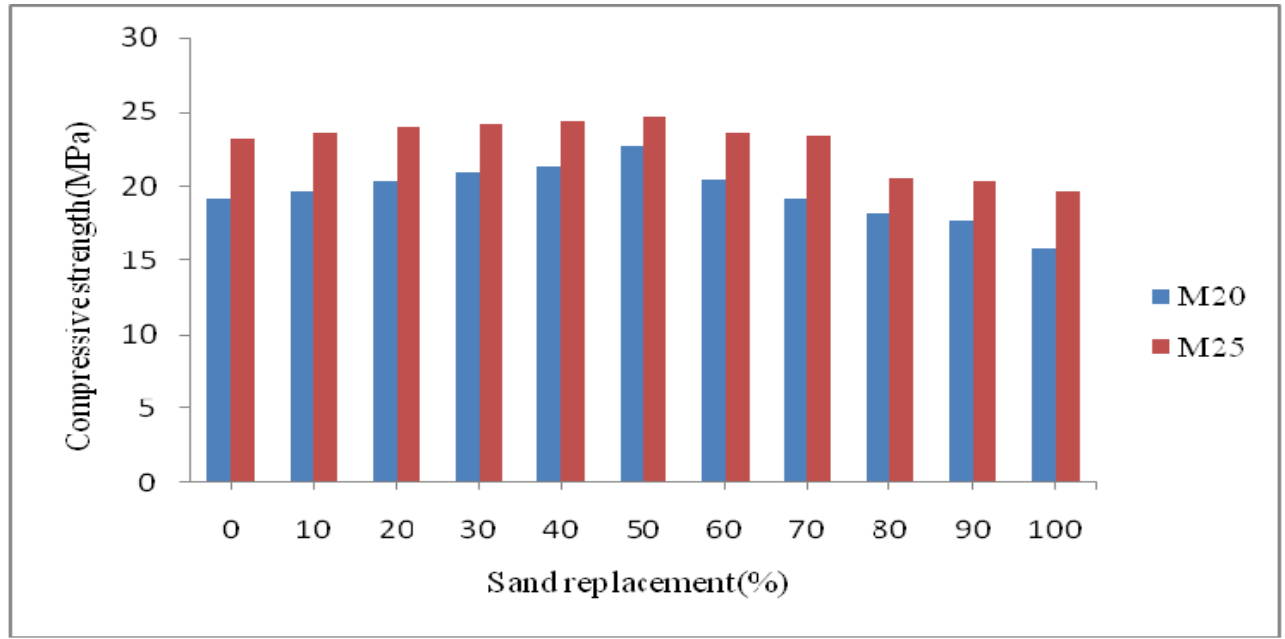

Figure 1: Compressive strength of concrete in 7 days 


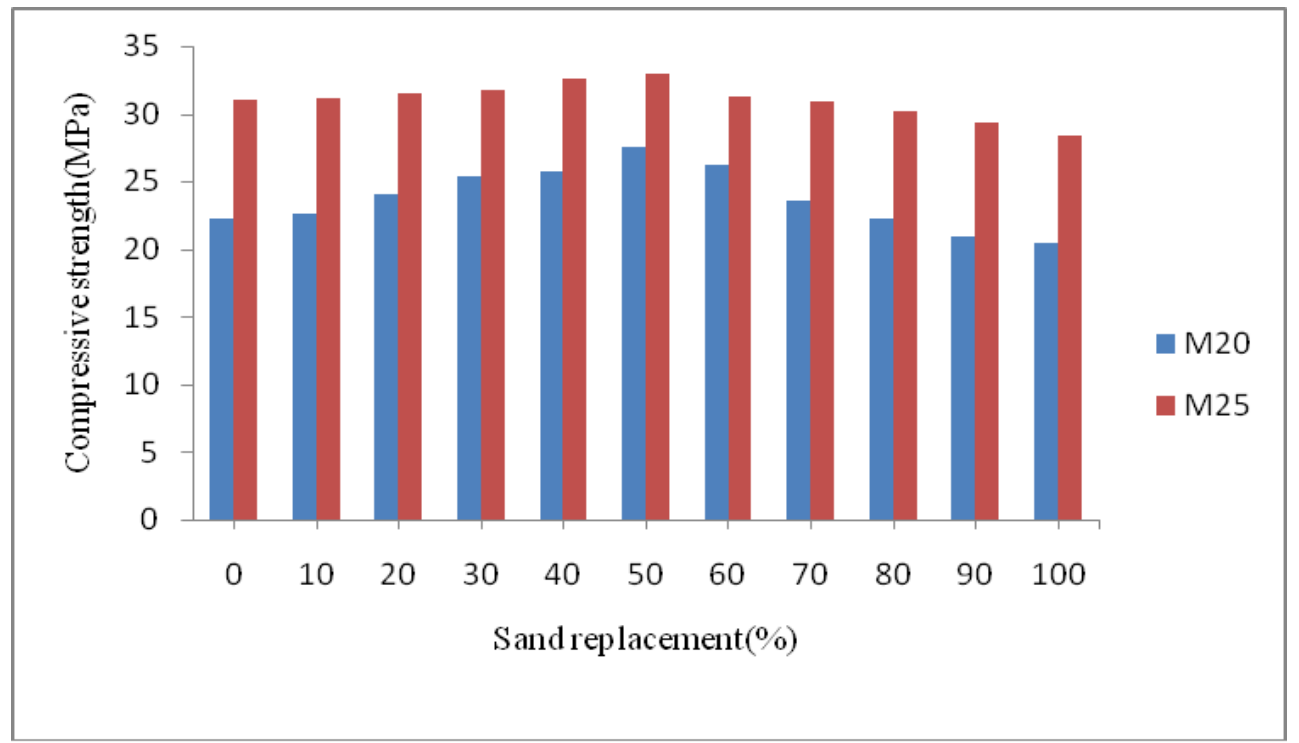

Figure 2: Compressive strength of concrete in 28 days

Due to increase in temperature the strength of concrete was affected. The reduction in strength due to increase in temperature is presented in Table 6 and 7. From those Tables, it is observed that the percentage of reduction in strength compared with control concrete is very less in 50\% sand replacement.

Table 6: Compressive strength of M20 concrete in 28 Days due to temperature effect

\begin{tabular}{|c|c|c|c|}
\hline \multirow{2}{*}{$\begin{array}{c}\text { Fine aggregate } \\
\text { Sand: Quarry dust }\end{array}$} & \multicolumn{2}{|c|}{ Compressive strength (MPa) } & $\begin{array}{c}\text { \% of reduction in } \\
\text { strength compared } \\
\text { with control } \\
\text { concrete }\end{array}$ \\
\hline $100: 0$ & $\begin{array}{c}\text { Normal } \\
\text { temperature }\end{array}$ & $\begin{array}{c}\text { After heated to } \\
\mathbf{1 0 0}^{\circ} \mathbf{C}\end{array}$ & 20.66 \\
\hline $90: 10$ & 22.22 & 17.63 & 17.69 \\
\hline $80: 20$ & 22.67 & 18.29 & 16.66 \\
\hline $70: 30$ & 24.00 & 18.52 & 16.34 \\
\hline $60: 40$ & 25.33 & 18.59 & 14.00 \\
\hline $\mathbf{5 0 : 5 0}$ & 25.77 & 19.11 & $\mathbf{6 . 6 7}$ \\
\hline $40: 60$ & $\mathbf{2 7 . 5 6}$ & $\mathbf{2 0 . 7 4}$ & 10.67 \\
\hline $30: 70$ & 26.22 & 19.85 & 12.34 \\
\hline $20: 80$ & 23.56 & 19.48 & 13.01 \\
\hline $10: 90$ & 22.22 & 19.33 & 20.03 \\
\hline $0: 100$ & 20.89 & 17.77 & 23.68 \\
\hline & 20.44 & 16.96 & \\
\hline
\end{tabular}

Table 7: Compressive strength of M25 concrete in 28 days due to temperature effect

\begin{tabular}{|c|c|c|c|}
\hline \multirow{2}{*}{$\begin{array}{c}\text { Fine aggregate } \\
\text { Sand: Quarry dust }\end{array}$} & \multicolumn{2}{|c|}{ Compressive strength (MPa) } & $\begin{array}{c}\text { \% of reduction in strength } \\
\text { compared with control } \\
\text { concrete }\end{array}$ \\
\cline { 2 - 3 } & $\begin{array}{c}\text { Normal } \\
\text { temperature }\end{array}$ & $\begin{array}{c}\text { After heated to } \\
\mathbf{1 0 0}^{\circ} \mathbf{C}\end{array}$ & 21.47 \\
\hline $100: 0$ & 31.03 & 24.37 & 21.05 \\
\hline $90: 10$ & 31.19 & 24.50 & 18.95 \\
\hline $80: 20$ & 31.52 & 25.15 & 18.18 \\
\hline $70: 30$ & 31.75 & 25.39 & 18.12 \\
\hline $60: 40$ & 32.54 & 25.41 & 13.80 \\
\hline $50: 50$ & 32.92 & 26.75 & 15.25 \\
\hline $40: 60$ & 31.33 & 26.30 & 18.95 \\
\hline $30: 70$ & 30.87 & 25.15 & 23.08 \\
\hline $20: 80$ & 30.24 & 23.87 & 26.62 \\
\hline $10: 90$ & 29.33 & 22.77 & 35.87 \\
\hline $0: 100$ & 28.33 & 19.90 & \\
\hline
\end{tabular}

Due to sudden cooling (thermo shock) the strength of concrete was affected. The reduction in strength due to thermo shock is presented in Table 8 and 9. From those Tables, it is observed that the percentage of reduction in strength compared with control concrete is very less in 50\% sand replacement. 
Table 8: Compressive strength of M20 concrete in 28 days due to thermo shock

\begin{tabular}{|c|c|c|c|}
\hline \multirow{2}{*}{$\begin{array}{c}\text { Fine aggregate } \\
\text { Sand: Quarry dust }\end{array}$} & \multicolumn{2}{|c|}{\begin{tabular}{c} 
Compressive strength (MPa) \\
Normal \\
\cline { 2 - 3 }
\end{tabular}} & $\begin{array}{c}\text { After thermo of reduction in strength } \\
\text { shock } \\
\text { compared with control } \\
\text { concrete }\end{array}$ \\
\hline $100: 0$ & 22.22 & 16.96 & 23.68 \\
\hline $90: 10$ & 22.67 & 17.50 & 21.25 \\
\hline $80: 20$ & 24.00 & 17.63 & 20.66 \\
\hline $70: 30$ & 25.33 & 17.77 & 20.03 \\
\hline $60: 40$ & 25.77 & 18.29 & 17.69 \\
\hline $\mathbf{5 0 : 5 0}$ & $\mathbf{2 7 . 5 6}$ & $\mathbf{1 9 . 3 3}$ & $\mathbf{1 3 . 0 1}$ \\
\hline $40: 60$ & 26.22 & 18.60 & 16.30 \\
\hline $30: 70$ & 23.56 & 18.52 & 16.66 \\
\hline $20: 80$ & 22.22 & 18.29 & 17.69 \\
\hline $10: 90$ & 20.89 & 17.50 & 21.25 \\
\hline $0: 100$ & 20.44 & 16.00 & 28.00 \\
\hline
\end{tabular}

Fig 3 and 4 represent the temperature effect on compressive strength of concrete. From the figures it is clear that if the concrete was exposed to high temperature and subjected to sudden cooling then the loss in compressive strength is more than loss due to temperature effect when compared with strength of concrete at normal temperature.

Table 9: Compressive strength of M25 concrete in 28 days due to thermo shock

\begin{tabular}{|c|c|c|c|}
\hline \multirow{2}{*}{$\begin{array}{c}\text { Fine aggregate } \\
\text { Sand: Quarry } \\
\text { dust }\end{array}$} & \multicolumn{2}{|c|}{ Compressive strength (MPa) } & \multirow{2}{*}{$\begin{array}{c}\% \text { of reduction in } \\
\text { strength compared } \\
\text { with control concrete }\end{array}$} \\
\hline & $\begin{array}{c}\text { Normal } \\
\text { temperature }\end{array}$ & $\begin{array}{c}\text { After thermo } \\
\text { shock }\end{array}$ & \\
\hline 100:0 & 31.03 & 22.22 & 28.40 \\
\hline $90: 10$ & 31.19 & 22.67 & 26.95 \\
\hline $80: 20$ & 31.52 & 23.56 & 24.08 \\
\hline $70: 30$ & 31.75 & 24.00 & 22.66 \\
\hline $60: 40$ & 32.54 & 24.37 & 21.47 \\
\hline 50:50 & 32.92 & 26.00 & 16.22 \\
\hline $40: 60$ & 31.33 & 25.33 & 18.37 \\
\hline $30: 70$ & 30.87 & 24.00 & 22.66 \\
\hline $20: 80$ & 30.24 & 22.22 & 28.40 \\
\hline $10: 90$ & 29.33 & 21.33 & 31.27 \\
\hline $0: 100$ & 28.33 & 18.29 & 41.06 \\
\hline
\end{tabular}

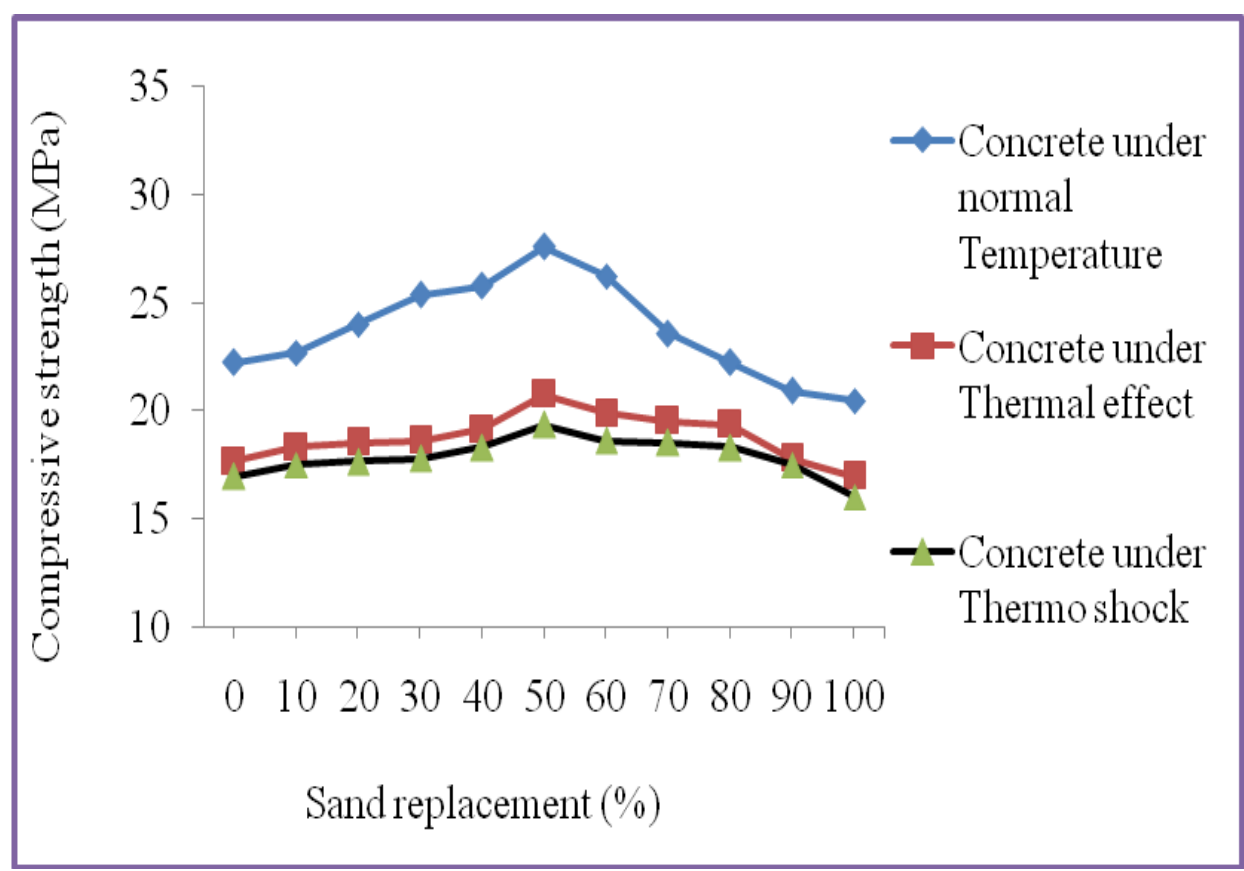

Figure 3: Temperature effect on compressive strength of M20 concrete 


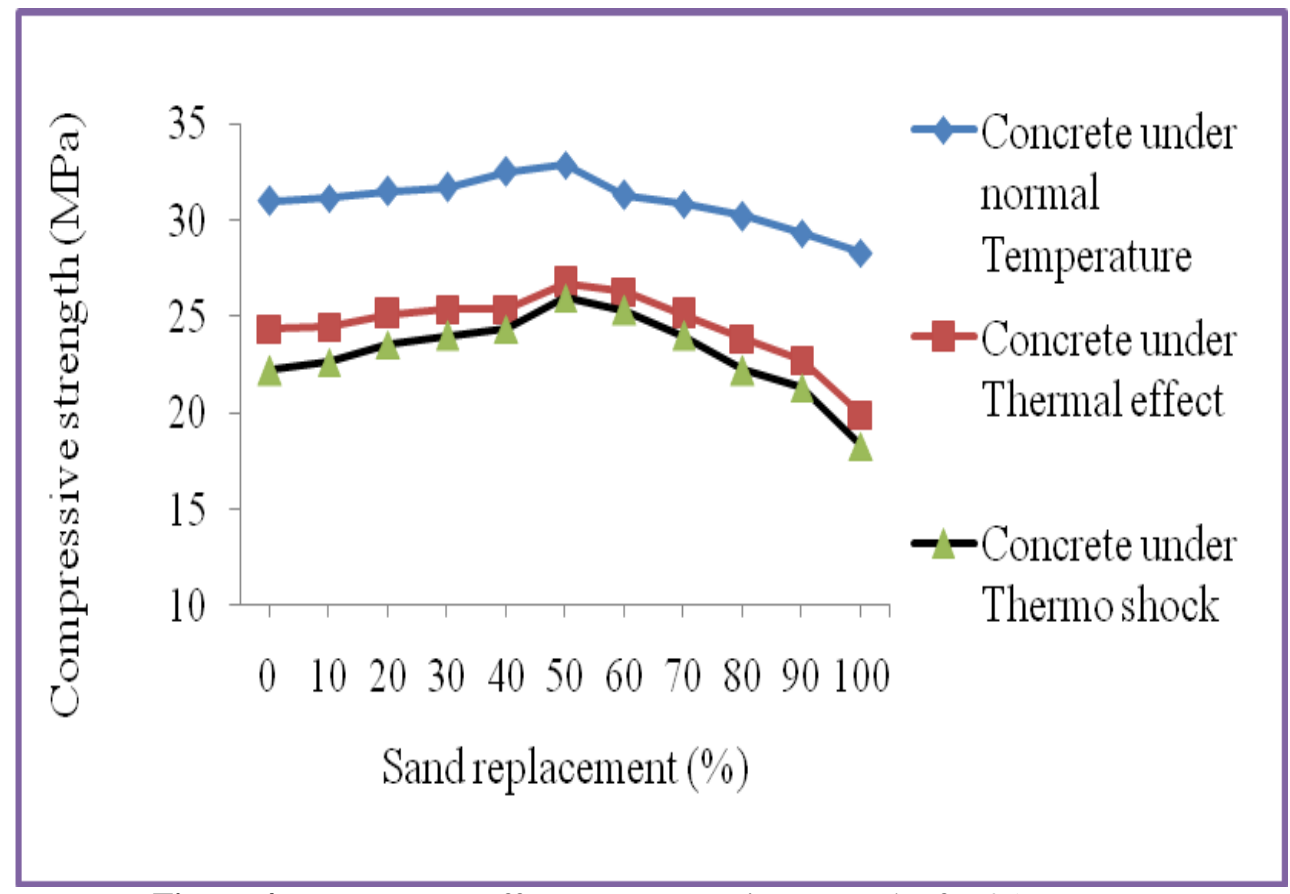

Figure 4: Temperature effect on compressive strength of M25 concrete

\section{Conclusions}

Based on above discussions, following conclusions are drawn;

1) Concrete acquires maximum increase in compressive strength at $50 \%$ sand replacement. The percentage of increase in strength with respect to control concrete is $24.04 \& 6.10$ in M20 and M25 respectively.

2) After heated to $100 \mathrm{oC}$, the maximum compressive strength is obtained at $50 \%$ sand replacement. The percentage of reduction in strength with respect to control concrete is $6.67 \& 13.80$ in M20 and M25 respectively.

3) Due to thermo shock also the compressive strength is maximum at $50 \%$ sand replacement only. The percentage of reduction in strength with respect to control concrete is $13.01 \& 16.22$ in M20 and M25 respectively.

The above conclusion gives clear picture that quarry dust can be utilized in concrete mixtures as a good substitute for natural river sand with higher strength at $50 \%$ replacement.

\section{References}

[1]. M.S. Shetty, Concrete Technology Theory and Practice, 5thedition, S.Chand \& Co. Ltd., New Delhi

[2]. I.R.Mithanthaya, Jayaprakash Narayan, Replacement of Sand by Quarry Dust for Plastering and in the Pavement Design, Proceedings of national Symposium at Karunya Institute of Technology on 20-21,December 2002, pp 9-15.

[3]. B.P.Hudson, Manufactured sand for concrete, The Indian Concrete Journal, May 1997, pp237-240.

[4]. M.S.Jaafar, W.A.Thanoon, M.R.A.Kadir and D.N.Trikha, Strength and Durability characteristics of high strength autoclaved stone dust concrete, The Indian concrete journal, December 2002, pp771-774.

[5]. A.K.Sahu, Sunil kumar and A.K.Sachan, Crushed stone waste as fine aggregate for concrete, The Indian Concrete Journal, January 2003 pp845-847.

[6]. IS456-2000 Indian standard code of practice for plain and reinforced concrete, Bureau of Indian standards, NewDelhi.

[7]. Md.Safiuddin, S.N.Raman and M.F.M. Zain, Utilization of Quarry waste fine Aggregate inconcrete mixures, 2007 Journal of Applied sciences research 3(3) : 202-208.

B.Basavaraj. "Replacement of Sand with Stone Crushed Powder in Conventional Concrete." IOSR Journal of Dental and Medical Sciences (IOSR-JDMS) 16.7 (2017): 01-06. 